\title{
Gastrin, motilin and pancreatic polypeptide levels after two different parenteral regimens in infants
}

\author{
J Ksiazyk 1, TL Peeters 2*, J Socha 1, V Bormans 2, \\ G Vantrappen 2 \\ 1 Department of Gastroenterology, Child Health Center, Warsaw, Poland; \\ 2 Center for Gastroenterological Research, University of Leuven, Belgium
}

(Received 21 November 1988 ; accepted 25 October 1989)

\begin{abstract}
Summary - We studied the effect of 2 different parenteral regimens upon gastrin, motilin and pancreatic polypeptide (PP) levels in infants. In 15 children, aged 1-25 months, plasma peptide levels were measured by radioimmunoassay in the fasting state and after a 2-h infusion of either a mixture of amino acids, glucose and lipids (A) or a mixture of amino acids and glucose (B) only. Wide interindividual fluctuations were noted, especially for motilin and PP, but, except for PP, intraindividual fluctuations were low. Indeed, a good correlation was found, not only between the 2 pre-infusion levels, but also between pre- and postinfusion levels in both experiments. In fact for all 3 peptides, pre- and postinfusion levels differed only slightly and non-significantly. We conclude that during parenteral feeding levels of motilin, PP and gastrin remain practically unchanged and are not influenced by the addition of lipids. In addition, during the observation period basal levels did not change, indicating that the mechanisms regulating basal secretion were not affected.
\end{abstract}

gastrin / motilin / pancreatic polypeptide / parenteral nutrition

Résumé - Effet de deux régimes de nutrition parentérale sur les taux de la gastrine, de la motlline et du peptide pancréatique chez les enfants. L'effet de deux régimes de nutrition parentérale sur les taux de la gastrine, de la motiline et du peptide pancréatique (PP) a été étudié chez 15 enfants, âgés de 1 à 25 mois. Le taux des peptides était déterminé par radioimmunoessai à jeun et après une infusion de $2 h$ de, soit un mélange acides aminés, glucose, lipides (A), soit un mélange acides aminés, glucose (B). Des fluctuations interindividuelles importantes ont été enregistrées, particulièrement pour la motiline et le PP mais, à part le PP, les fluctuations intraindividuelles étaient faibles. En effet, une bonne correlation a été trouvée, non seulement entre les taux avant l'infusion dans chaque étude, mais aussi entre les taux avant et après infusion dans les deux expériences. En fait, pour les trois peptides étudiés, les taux avant et après l'infusion étaient pratiquement inchangés. En conclusion, les taux de gastrine, de motiline et de PP ne sont pas influencés par les deux régimes parentéraux utilisés. De plus, pendant la période d'observation, les taux de base restaient constants, indiquant que les mécanismes de la sécrétion basale ne sont pas affectés par la nutrition parentérale.

gastrine / motiline / polypeptide pancréatique / nutrition parentérale

\footnotetext{
* Correspondence and reprints: TL Peeters, Gut Hormone Lab, Gasthuisberg O \& N, 3000 Leuven, Belgium
} 


\section{INTRODUCTION}

The digestive processes are at least partially regulated by the secretion of gastrointestinal hormones and the physiology of those hormones remains the subject of extensive research. A recent review was given by Walsh (1987).

It has been shown that in the newborn, elevations occur in basal plasma gut hormone levels (Rogers et al, 1974; Torsoli et al, 1975; Lucas et al, 1980a, b) and that the normalization to normal adult values and the establishment of the postprandial release pattern develop progressively (Lucas et al, 1978, 1980b). This development is probably triggered by oral feeding. Indeed, in infants who, on account of hyaline membrane disease received only intravenous glucose, no postnatal changes in motilin, gastrin, enteroglucagon, GIP or neurotensin could be found (Lucas et al, 1980b).

Parenteral nutrition is a specific method of nutritional support, which has to be used in certain conditions in which oral feeding is contraindicated. As the hormonal changes induced by oral feeding may play a role in the adaptive changes of the gastrointestinal system, parenteral feeding could have negative side-effects. In fact, it has been shown that total parenteral nutrition causes small intestinal hypoplasia in rats (Johnson et al, 1975) and increases the risk of gallstones developing in children (Roslyn et al, 1983). In patients with Crohn's disease, no change in fasted and postprandial levels of gut hormones was observed (Greenberg et al, 1981), but little is known about hormone secretion during parenteral feeding in infants. We have therefore studied the effect of 2 different parenteral regimens upon the release of gastrin, motilin and pancreatic polypeptide in infants fed parenterally because of surgery or protracted diarrhea.
Gastrin was chosen because it has been suggested to exert a trophic effect upon the gut mucosa, motilin because its release is somewhat linked to gallbladder contraction and PP because the postprandial changes of this peptide are pronounced.

\section{MATERIAL AND METHODS}

Fifteen children aged $1-25$ months $(7.5 \pm 6.2$ months) were entered into a prospective randomised crossover trial lasting 14 days with crossover on day 7 .

The patients were fed parenterally with Nutrimix-bags [B Braun] either with $3 \mathrm{~g} / \mathrm{kg}$ body weight (bw) lipids (A) or without lipids (B). Both regimens contained the same amount of amino acids $(2.5 \mathrm{~g} / \mathrm{kg} \mathrm{bw})$, but in regimen A $12.5 \mathrm{~g} / \mathrm{kg}$ bw glucose was administered versus $17.5 \mathrm{~g} / \mathrm{kg}$ bw in regimen $B$. The indications for parenteral nutrition were: protracted diarrhoea (5), intestinal resection (5) or œsophageal injury (5).

Blood samples were drawn in the fasted state (time 0) and following $120 \mathrm{~min}$ (time 120) of infusion. The infusion lasted for a total of $20 \mathrm{~h}$ in both studies. Blood samples were collected in a heparinised tube containing trasylol $(0.1 \mathrm{ml}$ for each $\mathrm{ml}$ blood) and immediately centrifuged. The plasma was immediately frozen at $-20^{\circ} \mathrm{C}$ and stored until assayed for motilin and PP. A separate serum sample was also prepared for the measurement of gastrin. The radioimmunoassay for gastrin was performed using commercially available reagents (Sorin-CEA). The antibody is directed against the $\mathrm{C}$-terminal end and recognizes gastrin-17 as well as gastrin-34. The cross-reaction is $72 \%$ (on a molar basis) for gastrin-34 at 50\% inhibition of binding. Our radioimmunoassay of motilin and PP has been previously described (Peeters et al, 1980; Janssens et al, 1982). The pancreatic polypeptide antibody, porcine pancreatic polypeptide (for labeling) and human pancreatic polypeptide (standard) were a gift from Dr RE Chance (Eli Lilly, Indianapolis, USA). The motilin antibody was prepared in rabbits; it recognizes the C-terminal part of the motilin molecule. Synthetic 13norleucine-motilin was used for labelling and as standard; it was obtained from Fluka AG 
(Buchs, Switzerland). The smallest amount of peptide measurable with $95 \%$ confidence using duplicate measurements was $10 \mathrm{pg} / \mathrm{ml}$ for gastrin, $16 \mathrm{pg} / \mathrm{ml}$ for $\mathrm{PP}$, and $2.5 \mathrm{pg} / \mathrm{ml}$ for motilin. Reference ranges established in our laboratory for normal adult volunteers are $0-100 \mathrm{pg} / \mathrm{ml}$ for gastrin, $0-500 \mathrm{pg} / \mathrm{ml}$ for motilin and $0-400 \mathrm{pg} / \mathrm{ml}$ for PP.

All results are expressed as means \pm standard error of the mean. Statistical analyses were performed by paired $t$-test (the distribution of the data was not significantly different from the normal distribution, as was checked by the Kolmogorov-Smirnov test). Correlation analysis was performed to study the relationship between the 2 estimations of the gut hormones.

\section{RESULTS}

Wide interindividual fluctuations were noted for the basal levels of the 3 peptides measured, but for gastrin and motilin, intraindividual variations were low. Indeed for these peptides, a good correlation was found between the pre-infusion levels obtained in each patient before the 2 studies. Thus, for gastrin the levels were $179 \pm 44$ (time 0 , study A) and $176 \pm 52$ (time 0 , study $B$ ) $\mathrm{pg} / \mathrm{ml}$ with a highly significant correlation between both $(r=0.888 ; P<$ $0.001)$. For motilin, the values were respectively $508 \pm 76(\mathrm{~A})$ and $516 \pm 77(\mathrm{~B}) \mathrm{pg} /$ $\mathrm{ml}$ and individual values also correlated well between both studies $\langle r=0.656 ; P<$ 0.02 ). For $P P$ the correspondence between both studies was poor, $256 \pm 50$ (A) and $379 \pm 78$ (B) $\mathrm{pg} / \mathrm{ml}(r=0.14 ; P<0.7)$. It will be noted that the mean basal levels of gastrin were rather elevated compared to the normal adult values. For motilin a small elevation was found and PP values were normal.

The effect of the infusion of both parenteral regimens on the plasma levels of both hormones is shown in figure 1. Gastrin levels did not change significantly : from 179 \pm 44 to $192 \pm 44(P<0.3)$ in study $A$ and from $176 \pm 52$ to $155 \pm 48$ in study $B(P<$ $0.7)$. In both studies, an almost perfect correlation was found between pre- and postinfusion levels (A: $r=0.975 ; P<0.001$; B: $r=0.963 ; P<0.001)$. Motilin levels decreased in both studies : from $508 \pm 76$ to $383 \pm 54 \mathrm{pg} / \mathrm{ml}$ in study $A(P<0.05)$ and from $516 \pm 77$ to $441 \pm 41(P<0.2)$ in study $B$. The decrease was only significant in study A. As for gastrin, in both studies pre- and post-infusion motilin levels were significantly correlated (A: $r=0.732 ; P<$ 0.01 ; B: $r=0.629 ; P<0.05$ ). PP-values fluctuated widely. In study $A$ they decreased from $256 \pm 50$ to $173 \pm 26$ and in study $B$ from $379 \pm 78$ to $357 \pm 104$, but due to the large standard error both changes are not significant (A: $P<0.1$; B: $P<$ $0.9)$. Only in study $A$ were pre- and post-infusion levels correlated $(r=0.589$; $P<0.05$ ).

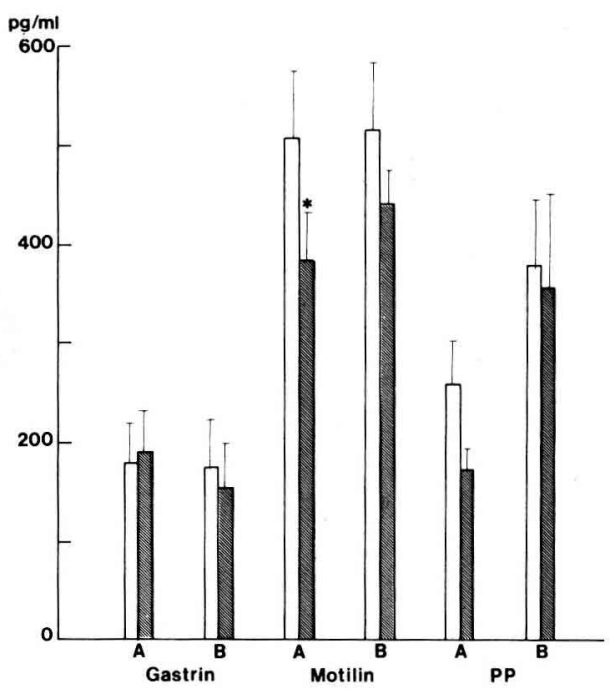

Fig 1. Effect of the infusion of 2 different parenteral regimens (A, with lipid; $B$, without lipid) upon plasma levels of gastrin, motilin and PP in 15 infants. The mean levels are shown at the start of the infusion ( $\square$ ) and $120 \mathrm{~min}$ later (圆). A significant difference $(P<0.05)$ is denoted by an asterisk. 
Considering the fact that there was a fairly good agreement between the basal levels of gastrin and motilin for both studies, it seemed justified to compare the post-infusion levels of both studies with each other. For motilin the difference (383 versus 441) is not significant, but for gastrin (192 versus 155) it is $(P<0.02)$.

\section{DISCUSSION}

Our results show that in the group of patients studied, basal levels of gastrin and motilin were elevated, that 2 different parenteral regimens had a minor effect upon those levels (only 1 regimen induced a decrease in motilin levels) and that hormone levels remained stable throughout the study. Although a small group of patients was studied, the results were more or less clearcut, and because of the problems associated with such a study in small infants, it was not expanded.

Profound changes in plasma hormone levels occur in the first weeks of life of the newborn. Some peptides are elevated at birth and others rise steeply during the very first week. During the second week of life the levels may continue to increase, as is the case for motilin and PP, or start to decrease, as is the case for gastrin and enteroglucagon (Lucas et al, 1980a, b). The time required to reach normal adult values is not known. For gastrin it has been reported that plasma levels are still elevated in children 2-3 yr old (Janik et al, 1977; Lucas et al, 1981).

In the patients studied, the basal levels of gastrin and motilin were also elevated. The increase was most pronounced for gastrin, confirming the long persistence of hypergastrinemia in infants. Increased hormone levels in the first year of life may be attributed to several factors, such as a greater importance of the endocrine cell mass, or as yet undeveloped regulatory mechanisms of secretion and metabolism. However, for motilin the increase, which was very moderate, may also be due to the fact that some of our patients suffered from diarrhea, a condition known to cause hypermotilinemia in infants (Lothe et al, 1987). Nevertheless, when considered separately, values for the 5 patients with protracted diarrhea did not differ from those of the other patients.

Our data show that during parenteral nutrition, the levels of gastrin and PP remain unchanged, regardless of the addition of lipids to the infusate. However, when added, motilin levels decreased significantly. Apart from the effect on motilin levels, the results seem to agree with what is known of the release mechanism of these peptides. Gastrin secretion is mainly stimulated by the presence of proteins or degradation products of proteins in the gastric lumen; its secretion is inhibited by a low gastric $\mathrm{pH}$. When applied to the gastric mucosa, the amino acids phenylalanine and tryptophan are the most potent gastrin-releases (Taylor et al, 1982), but although they stimulate acid secretion when given intravenously there is no concomitant release of gastrin (McArthur et al, 1983). Pancreatic polypeptide is also released by a protein-rich meal, but the vagus plays an important role as well. According to Floyd et al (1977) intravenous amino acids cause a small release, intravenous glucose suppresses PP levels. Upon prolonged fasting, PP levels rise as glucose levels fall. This response could be the result of increased vagal stimulation, as insulin-induced hypoglycemia causes a marked reduction in plasma PP-levels (Schwartz, 1983). It should be noted, however, that Adrian et al (1977) failed to find any effect of intravenous fat, amino acids or glucose upon plasma PP levels. Our data also appear to exclude any important 
effect of intravenous nutrients upon plasma PP levels. The intraindividual fluctuations, which were most important for this peptide, might be a reflection of the variability of the vagal tonus in the infants studied.

According to Christofides et al (1979) individual food components affect motilin levels to a similar extent whether given orally or intravenously. Thus fat stimulates, whereas glucose and amino acids inhibit its release. Our results do not agree with these data, as motilin decreased significantly when lipids were included. It should be noted, however, that the postprandial rise of motilin is short and transient. Our values were obtained after a $2 \mathrm{~h}$ infusion period and seem to confirm that the overall effect is a decrease in motilin levels.

Our study is the first to compare 2 parenteral regimens in a clinical condition. In principle, the addition of lipids should reproduce a more physiological situation, but as can be seen from our data, this does not appreciably change the release of the hormones studied. In fact, our studies confirm that during parenteral feeding, plasma hormone levels are rather stable. In addition, during the observation period basal levels did not change, indicating that the mechanisms regulating basal secretion are not affected and that the population of enteroendocrine cells remains unchanged. The same conclusion was reached by Greenberg et al (1981) who studied the hormonal response in adults after oral feeding, following a long period of total parenteral nutrition and found this to be normal. Therefore, in adults and infants, total parenteral nutrition does not seem to have negative effects upon the metabolism of the peptides studied.

During parenteral nutrition, the shortterm effects of peptides upon the secretory and absorptive processes of the gut are not necessary and apparently for this reas- on their release mechanisms are not triggered. A long-term effect such as the stimulation of growth of the gastrointestinal mucosa may depend upon the continued presence of low basal levels. Our study indicates that parenteral nutrition does not have a negative effect in this respect.

\section{ACKNOWLEDGMENTS}

This study has been supported by the Ministries of Health of Belgium and Poland as part of the exchange program between both countries.

\section{REFERENCES}

Adrian $\mathrm{T}$, Besterman $\mathrm{H}$, Cooke $\mathrm{T}$, Bloom $\mathrm{S}$, Barnes A, Russell R, Faber R (1977) Mechanism of pancreatic polypeptide release in man. Lancet i, 161-163

Christofides MD, Bloom SR, Besterman HS, Alnan TE, Ghatei MA (1979) Release of motilin by oral and intestinal nutrients in man. Gut 20, 102-106

Floyd J, Fajans S, Pek S, Chance RE (1977) A newly recognized pancreatic polypeptide; plasma levels in health and disease. Recent Prog Horm Res 33, 519-570

Greenberg GR, Wolman SL, Christofides ND, Bloom SR, Jeejeebhoy KN (1981) Effect of total parenteral nutrition on gut hormone release in humans. Gastroenterology $80,988-$ 993

Janik J, Akbar AM, Burrington JD, Burke G (1977) Serum gastrin levels in infants and children. Pediatrics 60, 60-64

Janssens J, Hellemans J, Adrian TE, Bloom SR, Peeters TL, Christofides N, Vantrappen G (1982) Pancreatic polypeptide is not involved in the regulation of the migrating motor complex in man. Regul Pept 3, 41-49

Johnson LR, Copeland EM, Duovick SJ, Lichtenberger LM, Castro GA (1975) Structural and hormonal alterations in the gastrointestinal tract of parenterally fed rats. Gastroenterology 68, 1177-1183 
Lothe L, Ivarsson SA, Lindberg I (1987) Motilin, vasoactive intestinal peptide and gastrin in infantile colic. Acta Paediatr Scand 76, 316320

Lucas A, Adrian TE, Bloom SR, Aynsley-Green A (1980a) Plasma pancreatic polypeptide in the human neonate. Acta Paediatr Scand 69, 211-214

Lucas A, Adrian TE, Christofides N, Bloom SR, Aynsley-Green A (1980b) Plasma motilin, gastrin and enteroglucagon and feeding in the human newborn. Arch Dis Child 55, 673677

Lucas A, Aynsley-Green A, Bloom SR (1981) Gut hormones and the first males. Clin $\mathrm{Sci}$ 60, 349-353

Lucas A, Bloom SR, Aynsley-Green A (1978) Metabolic and endocrine events at the time of the first feed of human milk in preterm and term infants. Arch Dis Child 53, 731-736

Lucas A, Bloom SR, Aynsley-Green A (1980) Development of gut hormone responses to feeding in neonates. Arch Dis Child 55, 678682

McArthur KE, Isenberg J, Hogan D, Dreier S (1983) Intravenous infusion of L-isomers of phenylalanine and tryptophan stimulates gastric acid secretion at physiologic plasma concentrations in normal subjects and after parietal cell vagotomy. J Clin Invest 71, 1254-1262

Peeters TL, Vantrappen G, Janssens J (1987) Fasting plasma motilin levels are related to the interdigestive motility complex. Gastroenterology 79, 716-719

Rogers JM, Davidson DC, Lawrence J, Buchanan KD (1975) Neonatal secretion of secretin. Arch Dis Child 50, 120-122

Roslyn JJ, Berquist WE, Pitt HA, Mann LL, Kangarloo H, Den Besten L, Ament ME (1983) Increased risk of gallstones in children receiving total parenteral nutrition. Pediatrics 71, 784-789

Schwartz T (1983) Pancreatic polypeptide: a unique model for vagal control of endocrine systems. J Auton Nerv Syst 9, 99-111

Taylor I, Byrne W, Christie D, Ament M, Walsh J (1982) Effect of individual L-amino acids on gastric acid secretion and serum gastrin and pancreatic polypeptide release in humans. Gastroenterology 83, 273-278

Torsoli A, Delle-Fave GF, Melchiori P, Sopranzi $N$, Kohn A (1975) Neonatal hypergastrinaemia in man. Gut 16, 834

Walsh JH (1987) Gastrointestinal hormones. In: Physiology of the Gastrointestinal Tract (Johnson LR, ed), Raven Press, NY, 181-253 